\title{
Studi Awal Perbandingan Anestesia Akupunktur dengan Anestesia Obat dari Aspek Gambaran Darah pada Domba
}

\author{
Raden Harry Soehartono \\ Departemen Klinik Reproduksi dan Patologi, Fakultas Kedokteran Hewan, Institut Pertanian Bogor
}

ABSTRAK: Perbandingan daya kerja anestesia akupunktur dengan anestesia obat melalui gambaran darah domba untuk menangani berbagai kasus operasi di lapangan. Pengamatan profil darah meliputi: Hb (Haemoglobine), PCV (Pack Cell Volume), SDM (Sel Darah Merah), SDP (Sel Darah Putih) dan diferensiasi Limfosit serta kimia klinik darah meliputi: Ca, Creatinin dan SGOT. Domba sebanyak 10 ekor mendapat 3 perlakuan dalam interval waktu tertentu, yaitu Akupunktur, Xylazin $\left(\right.$ Xylazil-20 ${ }^{\circledR}$ ) dan Pentobarbital $\left(\right.$ Nembutal $^{\circledR}$ ) dengan 3 periode percobaan, yaitu pre-anestesia, anestesia dan postanestesia. Hasil penelitian memperlihatkan ada variasi profil darah pada setiap perlakuan anastesia. Secara umum akupunktur meningkatkan kadar Hb, PCV, SDM dan SDP, sementara kimia klinik darah relatif konstan, sedangkan profil darah dari kedua obat bius bersifat menurun. Nilai kimia klinik darah baik perlakuan obat Xylazin dan akupunktur relatif sama, kecuali Pentobarbital mengakibatkan penurunan kurva limfosit dan $\mathrm{Ca}$, sedangkan Creatinin meningkat tajam.

Kata kunci:

akupunktur, analisa darah, anestesia, pentobarbital, xylazin

\section{- PENDAHULUAN}

Sistim fisiologis tubuh menurut filosofi akupunktur relatif berbeda dengan kedokteran secara umum (Kiswoyo dan Kusuma 1981), pengetahuan kedokteran yang lama dikenal dapat digunakan dalam menganalisa daya kerja akupunktur (Lee et al. 1982) dan (Ulet 1983). Jaringan magnetisme dalam tubuh mempunyai kekuatan aliran listrik, sehingga rangsangan jarum akupunktur akan menggertak sistim tubuh (Wesel 1980), terutama aliran persyarafan secara tidak langsung. Jaringan tubuh dalam ilmu akupunktur bekerjadalam sistim meridian yang menghubungkan titiktitik akupunktur sebagai pusat penerima dan penyalur rangsangan terletak dibawah lapisan kulit tertentu (Oetomo 1980) dan (Kiswoyo dan Kusuma 1981). Titik akupunktur tersebut berperan untuk pengobatan dengan memilih titik dalam kombinasinya (Laksmipathi 1983) dan (Aliambar et al. 1993). Hal ini mirip dengan penggunaan obat dalam pengobatan, yaitu pemilihan obat dengan kombinasi dari berbagai obat untuk penyembuhan.

\section{- BAHAN DAN METODE}

Hewan percobaan berjumlah 10 ekor domba betina muda yang berumur lebih kurang 1 tahun. Bahan obat bius, yaitu Xylazil-20® (Xylazin), Nembutal® (Pentobarbital) dan jarum-jarum akupunktur yang dibantu dengan elektroakupunktur (EA) model G.6850-2.

Administrasi obat bius Pentobarbital melalui vena jugularis sinistra hewan segera terbius, sedangkan Xylazin mela- lui intramuskuler di antara m. semitendinosus dan m. semimembranosus di dextra dan sinistra hewan menunggu beberapa menit sampai obat mulai bekerja. Pembiusan akupunktur melalui penusukan jarum-jarum akupunktur pada titik-titik akupunktur B1-30, Liv-14, Gov-30 dan St-36. Jarum dihubungkan dengan elektro-akupunktur (EA) sampai hewan terbius dengan tidak ada rasa sakit pada daerah operasi (kulit) bila dijepit dengan pinset atau ditusuk dengan jarum (Soehartono 2012). Pengamatan penelitian pada aspek profil darah meliputi: Hb (Haemoglobin), PCV (Pack Cell Volume), SDM (sel darah merah), SDP (sel darah putih) dan deferensiasi Limfosit. Sedangkan kimia klinik darah meliputi: Ca, Kreatinin, dan SGOT. Setiap domba dengan 3 perlakuan dalam interval waktu tertentu, yaitu Akupunktur, Xylazin dan Pentobarbital. Setiap perlakuan dibagi dalam 3 periode percobaan, yaitu preanestesia, anestesia, dan postanestesia. Dari 3 periode tersebut terbagi menjadi 5 kali pengambilan sampel darah.

\section{- HASIL DAN PEMBAHASAN}

Kadar $\mathrm{Hb}$ oleh perlakuan kedua jenis obat bius memperlihatkan penurunan cukup drastis pada periode preanestesia akhir, namun terjadi peningkatan pada periode anestesia (Gambar 1). Sedangkan pengaruh akupunktur

\footnotetext{
Diterima : 21 Juli 2017

Direvisi : 8 Agustus 2017

Disetujui : 11 Agustus 2017
} 

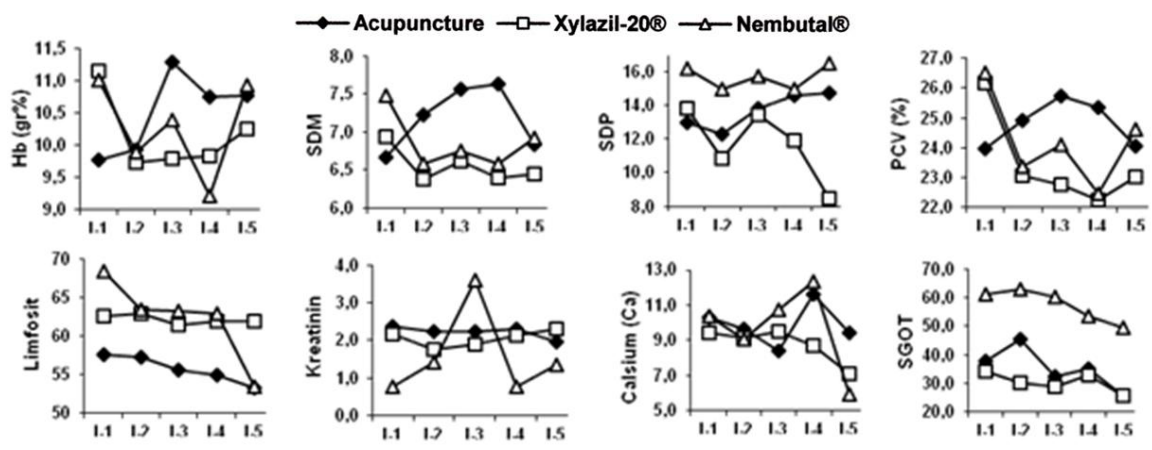

Periode Anestesi

Gambar 1. Analisa Darah dari Perbandingan Anestesia Akupunktur, Xylazin dan Pentobarbital

cenderung meningkatkan kadar $\mathrm{Hb}$, bahkan terjadi kenaikan yang cukup tinggi selama anestesia dibandingkan dengan kedua obat bius.

Jumlah SDM oleh perlakuan akupunktur membentuk kurva yang berlawanan dibandingkan dengan kedua jenis obat bius. Akupunktur menyebabkan peningkatan SDM, sedangkan kedua obat bius terjadi penurunan SDM selama periode anestesia, meskipun diakhir periode post-anestesia kembali konstan. Jumlah SDP meningkat selama anestesia oleh perlakuan akupunktur, karena pengaruh rangsangan akupunktur meningkatkan metabolisme tubuh. Sedangkan pada kedua obat bius relatif konstan, bahkan menurun pada perlakuan Xylazin. Hal ini akan mempengaruhi daya tahan tubuh selama anestesia dan post-anestesia. Bentuk kurva dari perubahan PCV mirip dengan SDM, karena PCV merupakan pencerminan dari SDM, sehingga bentuk kurva dari ketiga perlakuan tersebut relatif mirip. Pengaruh ketiga perlakuan terhadap jumlah Limfosit dalam deferensiasi darah relatif konstan, kecuali perlakuan Pentobarbital cenderung menurun diakhir periode post-anestesia. Jadi perubahan kadar Limfosit relatif konstan dan hanya terjadi dalam waktu beberapa hari kejadian suatu penyakit.

Pengaruh fisiologi Ca oleh ketiga perlakuan membentuk kurva relatif konstan sampai di periode anestesia. Kemudian kadar Ca meningkat di awal post-anetesia dan menurun di akhir periode post-anestesia. Hal ini dipengaruhi oleh kompensasi selama anestesia berlangsung. Perubahan kadar $\mathrm{Ca}$ akan cukup berarti selama operasi bila banyak perdarahan. Perubahan fisiologi Kreatinin oleh perlakuan Pentobarbital terjadi peningkatan cukup tajam selama periode anestesia, sedangkan perlakuan akupunktur dan Xylazin tidak memperlihatkan adanya perubahan kadar Kreatinin selama percobaan. Pentobarbital berpengaruh terhadap fungsi ginjal. Pengaruh fisiologi oleh ketiga perlakuan terhadap kadar SGOT relatif tidak merubah bentuk kurva, karena bila ada gangguan pada SGOT akan berpengaruh pada fungsi organ hati.

\section{- SIMPULAN}

Pembiusan akupunktur menyebabkan peningkatan jumlah darah dari profil darah (kadar Hb, PCV, SDM dan SDP), sedangkan Limfosit dan kimia klinik darah (Ca, Kreatinin,

10 | ARSHI Vet Lett, 2017, 1 (1): 9-10 dan SGOT) hampir tidak berubah. Hal ini sangat membantu dalam pemulihan kondisi badan setelah operasi. Jenis obat bius Xylazil-20® (Xylazin) dan Nembutal ${ }^{\circledR}$ (Pentobarbital) menurunkan jumlah sel darah, sehingga kondisi hewan perlu dijaga selama operasi (periode anestesia) dan postoperasi (periode post-anestesia). Kimia klinik darah oleh perlakuan Xylazin menunjukan tidak ada perubahan selama periode percobaan. Sedangkan perlakuan Pentobarbital menurunkan kadar Limfosit dan $\mathrm{Ca}$, sehingga perlu dijaga selama operasi dan post-operasi, terutama kadar Kreatinin sangat menurun tajam selama periode anesthesia dan postanestesia. Hal ini mengharuskan kondisi ginjal dalam keadaan prima sebelum anestesia dilakukan.

\section{- INFORMASI PENULIS}

Penulis untuk Korespondensi

days60s@gmail.com,days60s@yahoo.com.

\section{- PUSTAKA ACUAN}

Aliambar SH, Bawolye RR, Soehartono RH.1993. Manfaat Analgesia Akupunktur dalam Bedah Eksperimental untuk Menunjang Berbagai Kasus Penelitian Nutrisi pada Ternak. Laporan Penelitian. Bogor (ID): LP-IPB.

Kiswoyo, Kusuma A. 1981. Teori dan Praktek Akupunktur. Ed.2. Jakarta (ID): Penerbit PI Gramedia.

Laksmipathi GV. 1983. Acupuncture Anesthesia for Abdominal Surgery in Bovine. Am. Jour. of Acup. 11(1): 37-41.

Lee DC, Lee MO, Clifford OH, Movies LE. 1982. The Autonomic of Acupuncture and Analgesic Drugs on the Cardiovascular System. Am. Jour. of Acup. 10(1): 5-30.

Martono. 1982. Experimental Trial in the Use of Acupuncture as Anaesthesia in Performing Surgery on Small Animals. Report of the $3^{\text {rd }}$ Congress of the Federation of Asian Veterinary Association. Pp. 161-163.

Oetomo HS. 1980. Seni Akupunktur Modern. Jakarta (ID): Penerbit Bharata Karya Aksara.

Soehartono RH. 2012. The Comparison between Anesthesia Acupuncture and Anesthesia Drugs which are Conducted by Clinical Aspectin Sheep. Proceeding of International Conference Research and Aplication on Traditional Complementary and Alternative Medicine in Health Care (TCAM). Pp.146-151.

Ulet GA. 1983. Acupuncture is Not Hypnosis: Recent Physiological Studies. Am. Jour. of Acup.11(1): 5-13.

Wesel LO. 1980. Acupuncture for Americans. Reston Publishing Company, Inc. Pp. 79-104.

http://journal.ipb.ac.id/index.php/arshivetlett 